\title{
Three new species and one new record of Liris Fabricius (Hymenoptera: Crabronidae) from China, with a key to the Palaearctic species
}

\author{
Tingjing Li, Wanzhi Cai* \& Qiang Li
}

Li, T., Cai, W. \& Li, Q. 2009: Three new species and one new record of Liris Fabricius (Hymenoptera: Crabronidae) from China, with a key to the Palaearctic species. - Entomol. Fennica 20: 111-120.

Three new crabronid species, Liris claviformis sp. n., Liris clypefoveolatus sp. n., and Liris retirugosus sp. n., from Yunnan, China, are described and illustrated, and one new record for China, Liris agilis (F. Smith) from Xinjiang, is reported. A key to the Palaearctic species is provided.

T. Li, and W. Cai (*corresponding author), Department of Entomology, China Agricultural University, Yuanmingyuan West Road, Beijing 100094, China. Email:ltjing1979@hotmail.com; caiwz@cau.edu.cn

Q. Li, Department of Entomology, College of Plant Protection, Yunnan Agricultural University, Kunming, Yunnan 650201, China. E-mail: liqiangkm @126.com.

Received 10 June 2007, accepted 28 March 2008

\section{Introduction}

Liris Fabricius is a large cosmopolitan genus of the family Crabronidae. Richards (1928) and Beaumont (1961) revised the mediterranean species of Liris, respectively. Bohart and Menke (1976) listed 20 Palaearctic species. Kazenas (1978) provided a key to nine Palaearctic species of the genus. Pulawski listed 25 Palaearctic species of the genus in the electronic catalog of Sphecidae in April 2007, of which six species occur in Palaearctic, five in both Palaearctic and Oriental, nine in Palaearctic and Ethiopian, three in Palaearctic, Oriental and Australian, and two in Palaearctic, Oriental and Ethiopian regions. Ten Palaearctic species have been reported from China (Smith 1856, Bingham 1897, Cameron 1903, Dover 1926, Richards 1928, Gussakovskij 1938, Beaumont 1961, Bohart and Menke 1976, Tsuneki 1966, 1967, 1971, 1972, Pu 1986, Wu and
Zhou 1996, Porter et al. 1999, Pulawski 2007). During our study on the Chinese Liris, three new species and one new record from China were discovered.

Liris Fabricius is related to Larra Fabricius, and they share the following characters: lateral ocellus reduced, flat and small; frons just below medial ocellus with a transverse swelling extending from eye to eye and interrupted by medial frontal line, and a linear swelling along inner orbit which joins transverse swelling to form an $\mathrm{M}$ shape; fore wing with three submarginal cells; pronotum in angular in dorsal view, gaster without petiole. However, Liris can be differentiated from Larra by the following combination of characters: in female, last tarsomere angled in lateral view and surface parallel on apical half, pygidial plate in most species setose and with apically a transverse row of stout spinules; in male, lateral surface of propodeum impunctate and dull 

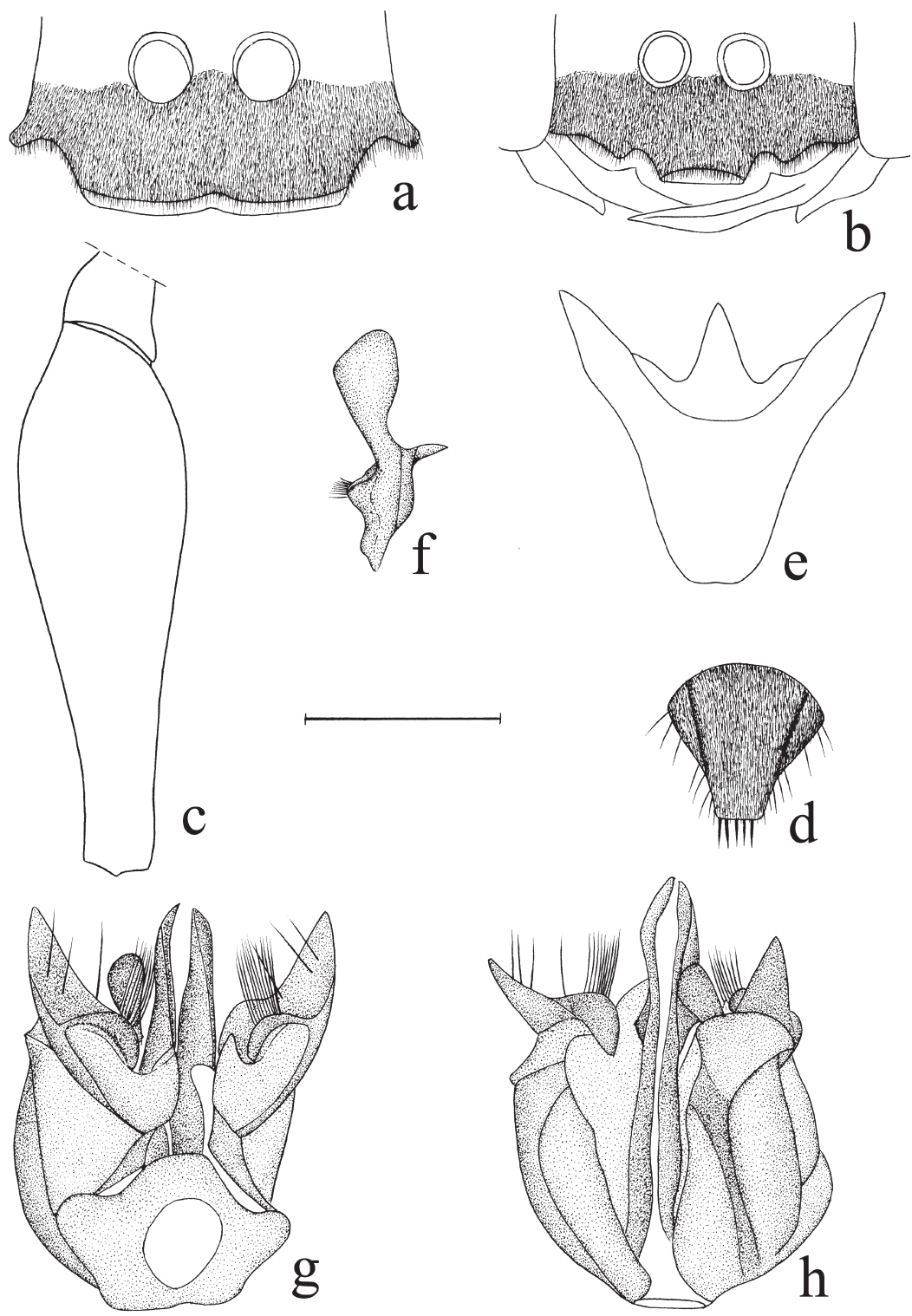

Fig. 1. Liris claviformis sp. n. a, c, d, o; b, e-h, o. - a. Frontal view of female clypeus. - b. Frontal view of male clypeus. - c. Hind femur of female. $-d$. Dorsal view of pygidial plate of female. $-\mathrm{e}$. Sternum VIII of male. $-f$. Lateral view of volsella of male. $-\mathrm{g}$. Frontal lateral view of paramere of male. - h. Dorsal lateral view of right paramere of male. Scale bar for $\mathrm{a}-\mathrm{d}$ $=1.0 \mathrm{~mm}$; for $\mathrm{e}-\mathrm{h}=$ $0.49 \mathrm{~mm}$.

or if shiny, then at most with sparse pinprick punctures, fore and hind femora excavated ventrally.

\section{Material and methods}

The material examined is deposited in Yunnan Agricultural University, Kunming (YNAU) and Institute of Zoology, Academia Sinica, Beijing (IZB), respectively. The specimens were observed and figured with the aid of an Olympus stereomicroscope with an ocular micrometer. The ratios throughout the descriptions were measured using the same magnification. For the terminology, we mainly follow Bohart and Menke (1976).

\section{Descriptions of new species}

\subsection{Liris claviformis sp. n. (Fig. 1)}

Material examined. Holotype, + , China, Yunnan, Jinping County, Mengla 420 m a.s.1., 21.IV.1956, 
Keren Huang. Paratype, $1 \hat{\partial}$, the same data as holotype. Deposited in IZB.

Description. Female. Body length $11.0 \mathrm{~mm}$. Black; mandible except base dark ferruginous; palpi, tibial and tarsal spines, tegula, stigma, and wings veins dark brown; wings hyaline, apex dark. Setae on head and thorax long, silvery, and soft, those on lower frons and clypeus distinctly thicker and shorter, those on gaster shorter, posterior margins of gastral segments I-IV with bands of silvery pile, respectively.

Head. Frons and vertex alutaceous and sparsely punctuate, punctures more than one diameter apart. Least interocular distance longer than flagellomere I. Length of flagellomere I about $2.7 \times$ its apical width, shorter than flagellomere II. Flagellomeres IV-IX with elongate elliptic placoids extending over about 1/6 the length of each segment, respectively. Lip of clypeus somewhat truncate and medially incised (Fig. 1a). Mandible basally with one tooth on inner margin.

Thorax. Pronotal collar and scutum densely punctuate, punctures less than one diameter apart, those on scutellum and metanotum sparser and more than one diameter apart; dorsum of propodeum with wide, shallow, and medial furrow, lateral carina, and dense, transverse and long rugae extending to lateral margin of propodeum and basally to mesopleural suture, intermixed with a few short, longitudinal rugae; lateral surface of propodeum densely, thinly and obliquely rugose; posterior surface of propodeum with medial furrow, side of furrow sparsely and transversely rugose. Length relation between abscissae of radial vein of fore wings: $5<2<3<1<4$. Hind femur (Fig. 1c) claviform, basally thickened, and gradually tapering toward apex.

Gaster. Pygidial plate (Fig. 1d) densely setose, apically truncate, and with 5 long and brown spinules; length of tergum I: width at posterior margin $=57: 100$.

Male. Body length $9.0 \mathrm{~mm}$. Scape and legs somewhat dark ferruginous. Least interocular distance as long as combined length of pedicel and flagellomere I. Length of flagellomere I about $1.7 \times$ its apical width, shorter than II. Flagellomeres II-XI with placoids, on II-X extending over full length of each segment, on XI extending over $3 / 4$ length of the segment. Lip of cly- peus truncate and not medially incised (Fig. 1b). Mid femur excavated ventrally, hind femur flat on inner side. Dorsum of propodeum more coarsely rugose than in female. Gaster without pygidial plate; length of tergum I : width at posterior margin $=73: 100$. Length relation between abscissae of radial vein of fore wings: $5<2<3<1<4$. Sternum VIII, volsella, paramere, and penis valve as in Fig. 1e-h, respectively. Other characters similar as in female.

Etymology. The specific name derives from Latin word claviformis, with reference to the hind femur claviform, basally thickened, and gradually tapering toward apex, which is one of the recognition characters for the species.

Diagnosis. The new species can be distinguished from the related L. philippinicus Tsuneki (1982) and all other congeners of the genus by the following combination of characters: lip of clypeus truncate in male, mandible basally with one tooth on inner margin, long, silvery, and soft setae on head and thorax, those on lower frons and clypeus distinctly thicker and shorter in both sexes, hind femur claviform, basally thickened, and gradually tapering toward apex in both sexes, and different shape of the genitalia.

Distribution. China: Yunnan (Fig. 4).

\subsection{Liris clypefoveolatus sp. n. (Fig. 2)}

Material examined. Holotype, đ̄, China, Yunnan, Dehongzhou City, Luxi County, West Outskirts of Fapa Town in Luxi City, 10.VIII.2005, Tingjing Li. Deposited in YNAU.

Description. Male. Body length $16.0 \mathrm{~mm}$. Black; palpi, tegula, stigma and veins dark brown to black; wings dark, with purple luster. Setae on head, thorax, and gaster silvery.

Head. Frons and vertex densely punctuate, punctures less than one diameter apart. Least interocular distance longer than flagellomere I, shorter than combined length of pedicel and flagellomere I. Length of flagellomere I about $2.7 \times$ its apical width, as long as II. Flagellomeres IIIIX with elongate elliptic placoids, on III about 1/5 length of segment, on IV about half of segment, on IV-IX longer than half of each segment. Surface of clypeus (Fig. 2a) gradually excavated except base, lip truncate. Mandible not notched on 

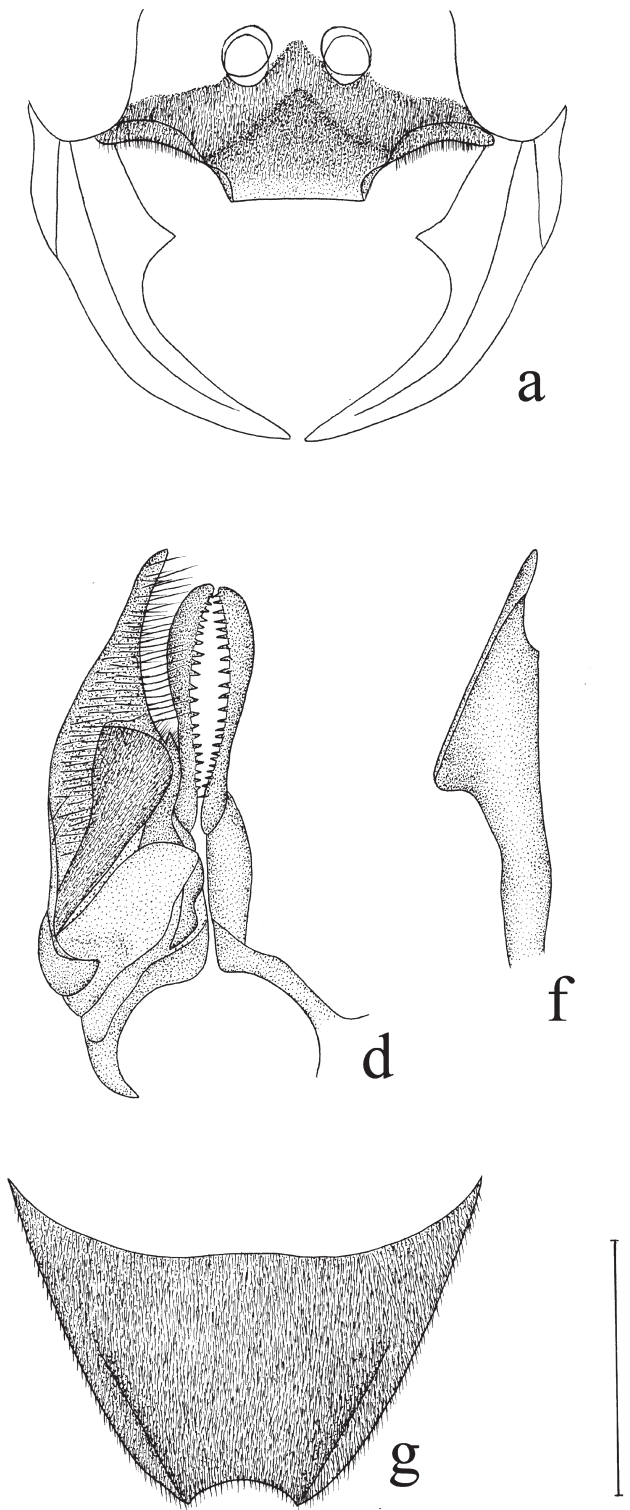

outer margin, and basally with one large triangular tooth on inner margin.

Thorax. Pronotal collar and scutum densely punctuate, punctures less than one diameter apart, scutellum and metanotum sparsely punctuate, punctures about one diameter apart; upper portion of metapleuron obliquely rugose, lower portion densely punctuate; dorsum of propodeum without lateral carina, with evanescent medial carina, and long transverse rugae extending to mesopleural suture and covering lateral surface of propodeum; posterior surface of propodeum
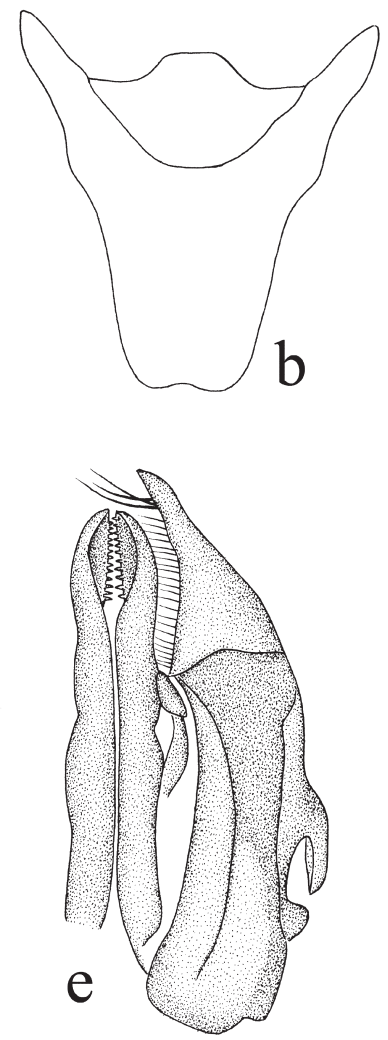

Fig. 2. Liris clypefoveolatus sp. n. Ô. - a. Frontal view of clypeus. - b. Sternum VIII. - c.

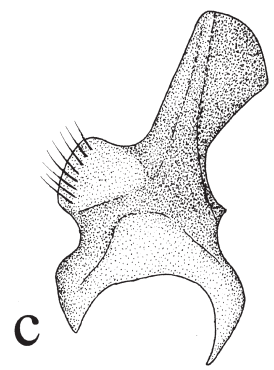
Lateral view of volsella. - d. Inside view of left paramere. - e. Dorsal view of left paramere. $-f$. Lateral view of penis valve. - g. Dorsal view of pygidial plate. Scale bar for $a=2.06$ $\mathrm{mm}$; for $\mathrm{b}, \mathrm{d}-\mathrm{g}=1.0$ $\mathrm{mm}$; for $\mathrm{c}=0.64 \mathrm{~mm}$.

with medial furrow, side of furrow transversely rugose. Length relation between abscissae of radial vein of fore wing: $2<5<3<1<4$.

Gaster. Pygidial plate (Fig. 2g) setose, apex concave; length of tergum I: width at posterior margin $=58: 100$. Sternum VIII, volsella, right paramere, and penis valve as in Fig. $2 \mathrm{~b}-\mathrm{f}$, respectively.

Female. Unknown.

Etymology. The name, clypefoveolatus, derived from Latin clype- (= clypeus) and Latin foveolatus (= sunken, depressed), refers to the 

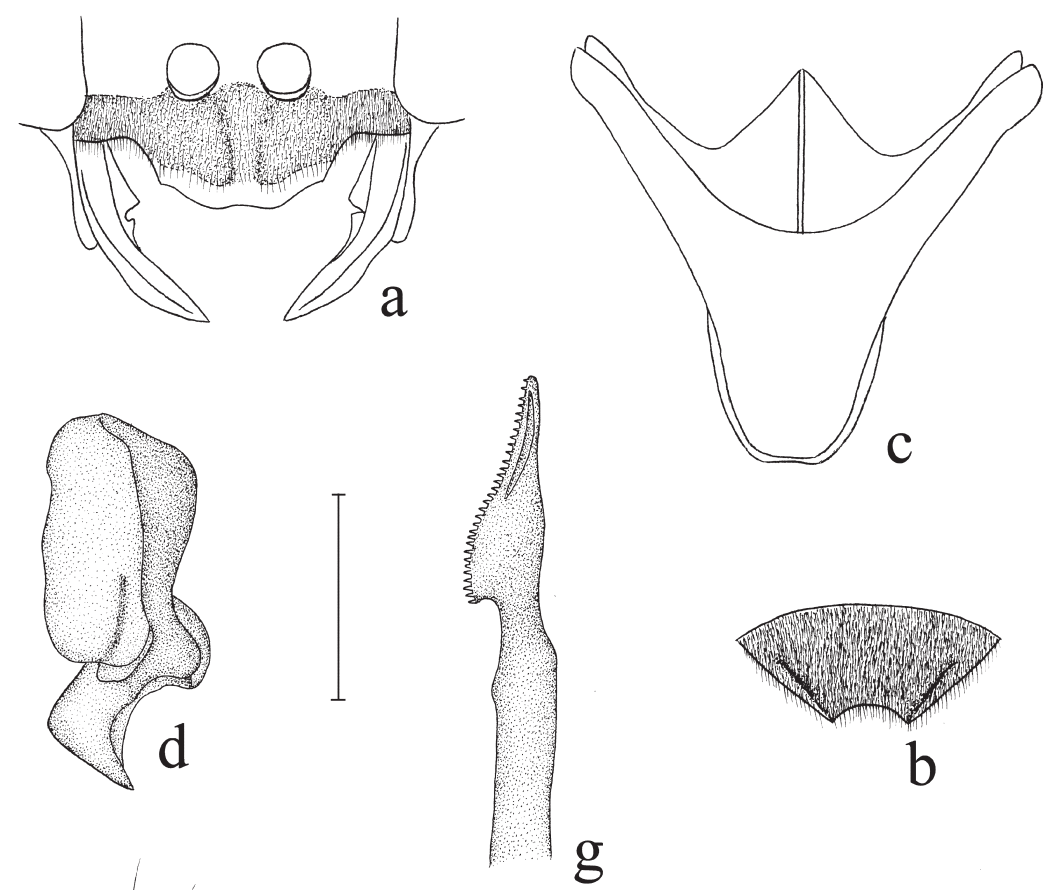

Fig. 3. Liris retirugosus sp. n. $\hat{o}$. - a. Frontal view of clypeus. $-b$. Dorsal view of pygidial plate. - c. Sternum VIII. - d. Lateral view of volsella. - e. Inside view of left paramere. $-f$. Dorsal view of left paramere. - g. Lateral view of penis valve. Scale bar for $a-b=1.0$ $\mathrm{mm}$; for $\mathrm{c}-\mathrm{g}=0.49 \mathrm{~mm}$.
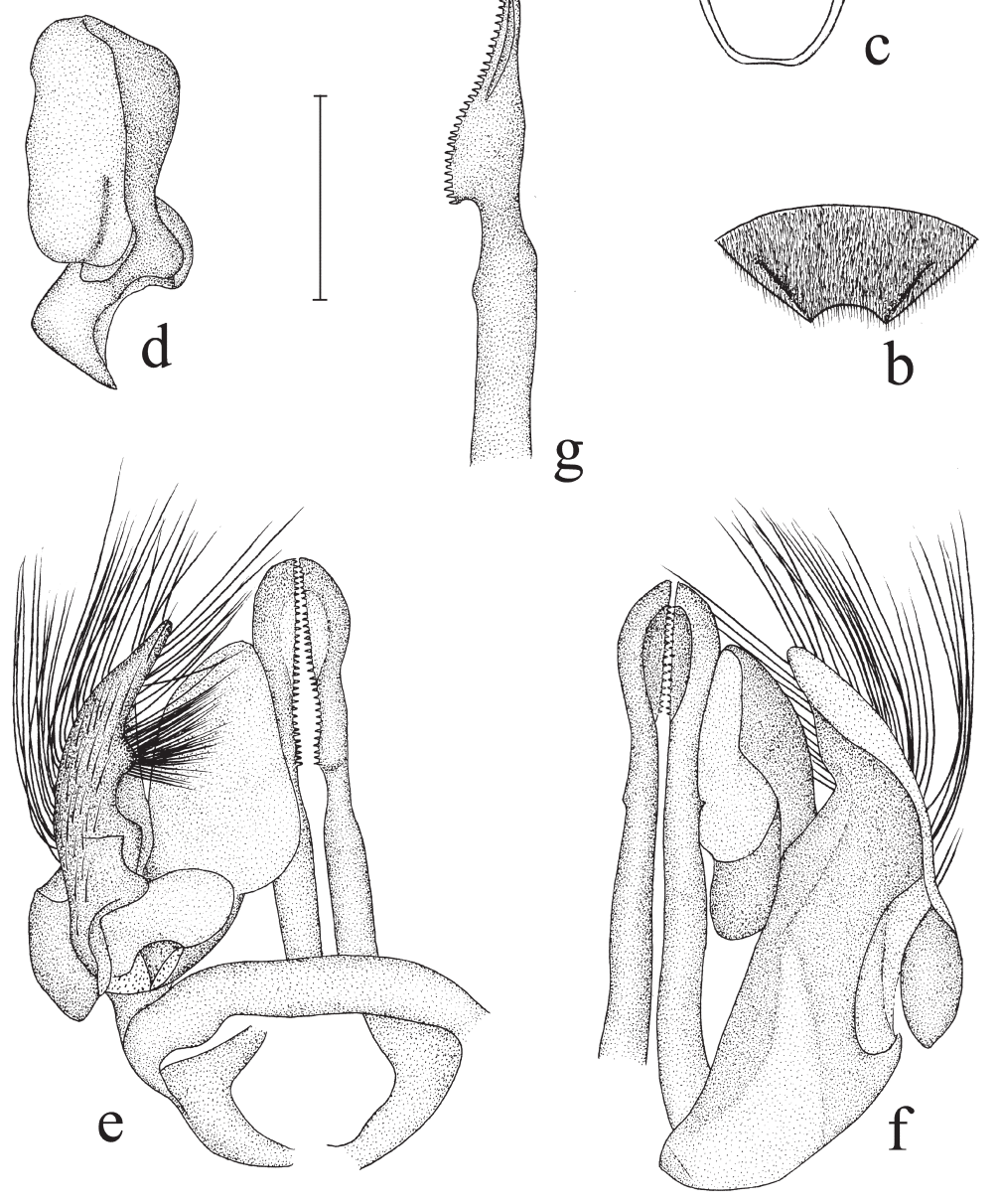

clypeus except base gradually excavated in male, which is one of the recognition characters for the species.

Diagnosis. This new species can be distinguished from a related L. aurulentus (Fabricius 1787) (redescribed by Tsuneki 1967: 27) and other congeners of the genus by the combination of the following characters: surface of clypeus gradually excavated except base and lip truncate, mandible basally with one large triangular tooth on inner margin, transverse and long rugae on dorsum of propodeum extending to mesopleural suture and covering lateral surface of propodeum, and different shape of the genitalia.

Distribution. China: Yunnan (Fig. 4).

\subsection{Liris retirugosus sp. n. (Fig. 3)}

Material examined. Holotype, đ̄, China, Yunnan, Simao City, Jingdong County, Jinping Town, 
Western Mountain, 1.V.2005, Chunju Liu, deposited in YNAU. Paratypes, $1 \hat{\jmath}$, same data as holotype; $1 \overbrace{}^{\lambda}$, China, Yunnan, Baoshan City, Tengchong County, Jietou Town, Datang Village, 15.VII.2006, Rui Zhang, deposited in YNAU; 1§̄, China, Yunnan, Hekou County $200 \mathrm{~m}$ a.s.1., 12.VI.1956, B. Bobofu; 1ð, China, Yunnan, Jinghong City, Menghai County, Menglongbannasong, 27.IV.1958, Fuji Pu, deposited in IZB.

Description. Male. Body length 9.0-12.0 $\mathrm{mm}$. Black; mandible apically ferruginous; palpi, tegula, stigma and veins dark brown; tibial and tarsal spines pale brown; wings hyaline, pale brown, apically dark. Setae on head, thorax and gaster silvery, those on lower frons, clypeus, and gena shorter, thicker, and denser; posterior margins of gastral segments I-III with bands of silvery pile, setae on gastral tergum VII (Fig. 3b) dense and brown.

Head. Frons and vertex densely punctuate, punctures less than one diameter apart. Least interocular distance nearly as long as combined length of pedicel and flagellomere I. Length of flagellomere I about $1.9 \times$ its apical width, as long as II. Flagellomeres II-XI with placoids, on II-X extending over full length of each segment, on $\mathrm{X}$ extending over $3 / 4$ length of the segment. Clypeus (Fig. 3a) with a medial longitudinal ridge, lip rounded and medially incised. Mandible basally with two teeth on inner margin.

Thorax. Scutum densely and largely punctuate, punctures distinctly less than one diameter apart; mesopleuron and metapleuron longitudinally and obliquely rugose, respectively; dorsum of propodeum longitudinally rugose, with medial carina covering about $2 / 3$ length of dorsum, without lateral carina; lateral surface of propodeum coarsely and obliquely rugose; posterior surface of propodeum with medial furrow, side of furrow sparsely and transversely rugose. Length relation between abscissae of radial vein of fore wings: 2 $<5<3<1<4$.

Gaster. Pygidial plate (Fig. 3b) setose, apically concave, and its maximal width distinctly greater than length; length of tergum I: width at posterior margin $=89$ : 100 . Sternum VIII, volsella, right paramere, and penis valve as in Fig. $3 \mathrm{c}-\mathrm{g}$, respectively.

Female. Unknown.

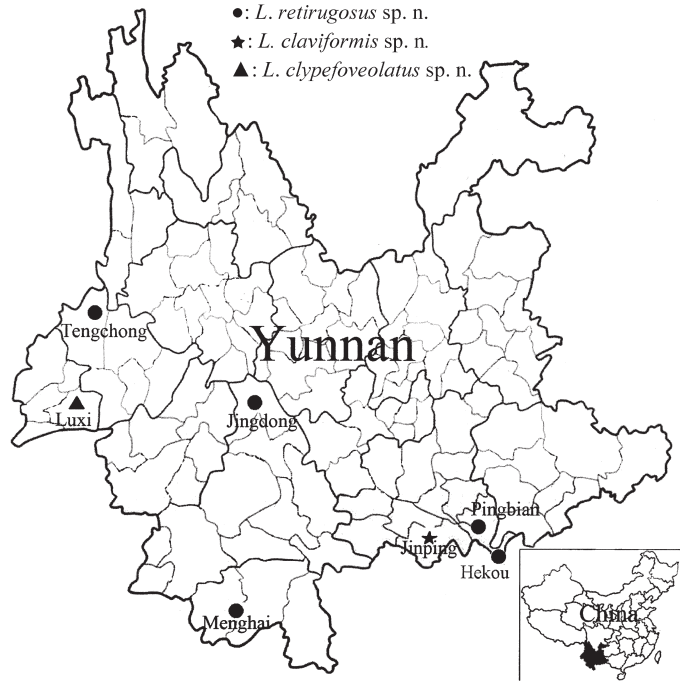

Fig. 4. Localities where the three new species of Liris have been recorded in Yunnan, China.

Etymology. The name, retirugosus, derived from Latin ret- (= reticulate, net-shaped) and Latin rugosus (= with rugae), refers to the dorsum of propodeum reticularly rugose, which is one of the recognition characters for the species.

Diagnosis. This new species can be distinguished from a related L. silvicola (Williams 1928), and other congeners of the genus by the following combination of characters: lip of clypeus rounded and medially incised, tibial and tarsal spines pale brown, dorsum of propodeum reticularly rugose, and different shape of the genitalia.

Distribution. China: Yunnan (Fig. 4).

\section{Key to the species of Liris from Palaearctic region}

\subsection{Females}

Females of L. maidli Arnold, L. iriomotensis Tsuneki, L. clypefoveolatus sp. n., and L. retirugosus sp. n. are unknown.

1. Mandible not notched on outer margin 2

- Mandible distinctly notched on outer margin

2. Setae on head and thorax appressed and golden; legs largely ferruginous 
- Setae on head and thorax silvery; legs largely black

3. Wings dark, with purple luster. Japan, South Asia, China (Yunnan, Taiwan)

\section{L. aurulentus (Fabricius)}

- Wings yellow and only apical portion dark. Africa, Egypt, Iraq, Mediterranean

\section{L. haemorrhoidalis (Fabricius)}

4. Sternum of gastral II at base distinctly protuberant; mandible and antennae black. Arabia, Mediterranean

L. gibbosus Kohl

- Sternum of gastral II not protuberant; mandible and antennae partly ferruginous. Arabia, Central Asia, Egypt, Israel, Mediterranean, Pakistan L. braueriKohl

5. Mesonotum and mesopleuron shining and punctuate

- Mesonotum and mesopleuron coriaceous or rugose

6. Mesopleuron sparsely punctuate. Africa, China (Jiangsu), Southwestern and Central Asia, Southwestern Europe

L. nigricans (Walker)

- Mesopleuron finely and densely punctuate 7

7. Gaster with four bands of silvery pile. China (Yunnan, Taiwan), Japan, Philippines, Thailand L.albopilosus Tsuneki

- Gaster with three bands of silvery pile 8

8. Lateral surface of propodeum coarsely reticulate. China (Yunnan, Taiwan), Japan, Korea, Thailand L.festinansjaponicus (Kohl)

- Lateral surface of propodeum punctuate or obliquely rugose, not reticulate. Egypt, Europe L.festinans praetermissus (Richards)

9. Tarsal claw toothed; hind tibia somewhat bent. Cyprus, Greece, Israel, Western Europe L. inopinatus de Beaumont

- Tarsal claw not toothed; hind tibia distinctly straight

10. Fore wing with dark and truncate band; length of third submarginal cell somewhat greater than its height. Central Africa, Mediterranean, Zimbabwe

L. miscophoides Arnold

- Fore wing without dark and truncate band; length of third submarginal cell distinctly greater than its height

11

11. Lip of clypeus truncate or somewhat protrudent medially; pygidial plate densely punctuate, and asetose or partly and sparsely setose

- Lip of clypeus with medial incision (Fig.1a); pygidial plate sparsely punctuate, and densely setose

12. Lip of clypeus truncate; pygidial plate only asetose basally

- Lip of clypeus medially more or less protrudent, pygidial plate asetose or mostly asetose

13. Pile on gaster ferruginous; wings dark, with purple luster. Europe, North Africa, Pakistan

L. atratus (Spinola)

- Pile on gaster silvery; wings light. Egypt, Israel, Sudan L.cleopatra de Beaumont

14. Pygidial plate apically, sparsely and largely punctuate; lateral surface of propodeum not rugose. Algeria, Central Asia

L. opalipennis (Kohl)

- Pygidial plate apically and densely punctuate; lateral surface of propodeum rugose $\quad 15$

15. Apical portion of fore wing dark; lip of clypeus dark ferruginous; length of pygidial plate about $2 \times$ its maximal width. Burma, Europe, India, Malaysia, Mongolia, Morocco

L. niger (Fabricius)

- Apical portion of fore wing light; lip of clypeus black; length of pygidial plate about $1.5 \times$ its maximal width. Egypt, Gambia, Mauritania, Mediterranean, Oman

L. agilis (F. Smith)

16. Setae on head and thorax golden, gaster with three golden bands of pile. India, Indonesia, Japan, Sri Lanka L. deplanatus (Kohl)

- Setae on head and thorax and pile on gaster silvery

17. Hind femur (Fig. 1c) basally thickened, gradually tapering toward apex. China (Yunnan)

L. claviformis sp. n.

- Hind femur not gradually tapering toward apex

18. Hind femur ferruginous $\quad 19$

- Hind femur black 20

19. Hind tibia ferruginous; wings distinctly yellow. Mediterranean, Africa

L. solstitialis (F. Smith)

- Hind tibia black; wings pale yellow. China (Yunnan and Taiwan), Fiji, Iraq, Japan, Mediterranean, South Asia

some specimens of $L$. subtessellatus

(F. Smith) 
20. Carina on hind tibia curved; gaster with four bands of pile

- Carina on hind tibia straight; gaster with three bands of pile

21. Lateral surface of propodeum coarsely rugose. Africa, Egypt, Mediterranean

L. memnonius (F. Smith)

- Lateral surface of propodeum distinctly smooth. Mediterranean, Yemen

L. trivittatus (W.F. Kirby)

22. Wings strongly dark, with purplish lustre, three bands of pile on gaster brown, and ill defined; setae of pygidial plate brown. Japan, China (Taiwan, Yunnan)

L. surusumi Tsuneki

- Wings light, without purplish lustre; pile on gaster lvery

23. Front and mid femora ventrally without pile. Central Asia, Egypt, Israel, Sudan

L. subfasciatus (Walker)

- Front and mid femora ventrally with silvery pile

24. Lateral surface of propodeum reticulate. Burma, China (Guangxi), India, Indonesia, Japan

L. tristis (F. Smith)

- Lateral surface of propodeum obliquely rugose

25. Anterior bevel of clypeus somewhat near median area, impunctate and polished. Japan, China (Taiwan), Malaysia, Philippines, Thailand

L. difficilis Tsuneki

- Anterior bevel of clypeus away from median area, with transverse series of punctures below, or sparsely punctuate

some specimens of L. subtessellatus

(F. Smith)

\subsection{Males}

Male of L. gibbosus is unknown.

1. Mandible not notched on outer margin 2

- Mandible distinctly notched on outer margin

2. Wings yellow and apically dark; hind tarsomere II dilated

L. haemorrhoidalis (Fabricius)

- Wings dark, with purple luster; hind tarsomere II not dilated
3. Surface of clypeus gradually excavated except base, lip truncate (Fig. 2a). China (Yunnan) L.clypefoveolatus sp.n.

- Surface of clypeus not gradually excavated, lip rounded

4. Setae on head and thorax appressed and golden; legs largely ferruginous

L. aurulentus (Fabricius)

- Setae on head and thorax silvery; legs largely black

L. braueri Kohl

5. Mesonotum and mesopleuron shining and obviously punctuate

6

- Mesonotum and mesopleuron coriaceous or rugose

6. Lip of clypeus medially toothed 7

- Lip of clypeus not medially toothed 8

7. Apex of gastral sternum IV and whole of gastral sternum V-VI with distinct long setae, the setae longer than those on other portions

L. nigricans (Walker)

- Apex of gastral sternum IV and whole of gastral sternum V-VI without distinctly long setae

L. albopilosus Tsuneki

8. Lip of clypeus somewhat rounded

L.festinans japonicus (Kohl)

- Lip of clypeus truncate

L. festinans praetermissus (Richards)

9. Hind femur ferruginous 10

- Hind femur black

10. Hind tibia ferruginous

- Hind tibia black

L. solstitialis (F. Smith)

some specimen of L. subtessellatus

(F. Smith)

11. Hind femur excavated ventrally so as to leave a projecting angle near the base

- Hind femur not excavated ventrally to leave a projecting angle near the base $\quad 17$

12. Gaster with four bands of silvery pile 13

- Gaster with three bands of silvery pile 14

13. Hind femur more strongly excavated; front and mid femora nearly asetose

L. memnonius (F. Smith)

- Hind femur less strongly excavated; front and mid femora densely setose

L. trivittatus (W.F. Kirby)

14. Gastral sternum V laterally with long fringe of setae L. subfasciatus (Walker)

- Gastral sternum V laterally without long fringe of setae 
15. Dorsum of propodeum reticulate, lateral surface coarsely and obliquely rugose; lip of clypeus (Fig. 3a) rounded, with medial incision

Liris retirugosus sp. $\mathrm{n}$.

- Dorsum of propodeum transversely rugose, lateral surface not coarse; lip of clypeus somewhat rounded, with indistinct medial incision

16

16. Fore femur somewhat excavated ventrally, paramere of the male genitalia slender

\section{L. difficilis Tsuneki}

- Fore femur strongly excavated ventrally, paramere of the male genitalia stout

some specimens of $L$. subtessellatus (F. Smith)

17. Hind femur grooved ventrally

- Hind femur not grooved ventrally

18. Wings strongly dark; hind femur angled ventrally and basally

L. atratus (Spinola)

- Wings apically dark; hind femur not angled ventrally and basally

L. cleopatra de Beaumont

19. Marginal cell of fore wing apically truncate and enlarged

- Marginal cell of fore wing apically not truncate and enlarged

20. Fore wing with dark and truncate band; length of third submarginal cell somewhat greater than its height

L. miscophoides Arnold

- Fore wing without dark and truncate band; length of third submarginal cell distinctly greater than its height L. maidli (Arnold)

21. Lip of clypeus truncate (Fig. 1b); hind femur claviform, thickened at base, gradually tapering toward apex L. claviformis sp. n.

- Lip of clypeus round or protrudent; hind femur not gradually tapering toward apex 22

22. Gaster with four bands of pile

$$
\text { L. inopinatus de Beaumont }
$$

- Gaster with three bands of pile

23. Wings strongly dark, with purplish lustre; setae on frons and clypeus pale yellow

\section{L. surusumi Tsuneki}

- Wings light, without purplish lustre; setae on frons and clypeus not silvery

24. Pronotum thick, not transversely carinate on top, medially raised nearly to level of scutum. Japan L.iriomotensis Tsuneki

- Pronotum normal
25. Lip of clypeus dull

L. niger (Fabricius)

- Lip of clypeus shining

26

26. Each of antennal segment short; propodeum somewhat rugose L.opalipennis (Kohl)

- Each of antennal segment long; propodeum distinctly rugose

L. agilis (F. Smith)

\section{First record of Liris agilis (F. Smith), 1856 from China}

Material examined. $2 \circ \bigcirc 6 \hat{\jmath}$, China, Xinjiang, Shihezi City, Fukang County, Cainanyoutian Desert, 3.VI.2006, Tingjing Li; 1 $\widehat{\jmath}$, China, Xinjiang, Tianshan, 6.VII.2005, Jianxin Cui. Deposited in YNAU.

Distribution. China (Xinjiang), Egypt, Gambia, Mauritania, Mediterranean, Oman.

Acknowledgments. We are grateful to Wojciech J. Pulawski (California Academy of Sciences, California) for providing us with the references, and to Professor Yan-Ru Wu (Institute of Zoology, Academia Sinica, Beijing), Professor Junhua He and Professor Xuexin Chen (Zhejiang University, Hangzhou), and Professor Zaifu Xu (South China Agricultural University, Guangzhou) for providing us with the specimens deposited in the insect collections under their care. This study was funded by the National Natural Science Foundation of China (30460025, 30660105), the Ministry of Science and Technology of China (2006FY120100), and the Science and Technology Department of Yunnan (2003RC01).

\section{References}

Beaumont, J. De. 1961: Les Liris du bassin méditerranéen (Hymenoptea Sphecidae). - Mitteilungen der Schweizerischen Entomologischen Gesellschaft 34: 213-252.

Bingham, C. T. 1897: The fauna of British India, including Ceylon and Burma. - In: Hymenoptera, Vol. I, Wasps and Bees. Taylor and Francis, London, 579 pp.

Bohart, R. M. \& Menke, A. S. 1976: Subfamily Larrinae. — In: Bohart, R. M. \& Menke, A. S. 1976 (eds), Sphecid Wasps of the World: 221-355. University of California Press, Berkeley, Los Angeles, London. IX.

Cameron, P. 1903: Descriptions of nineteen new species of Larridae, Odynerus and Apidae from Barrackpore. The Transactions of the Entomological Society of London, Part 1: 117-132.

Dover, C. 1926: A contribution to a list of the aculeate Hymenoptera (excepting ants) of Hongkong. - China Journal of Science and Arts 4: 233-235. 
Gussakovskij, V. V. 1938: Dir. Kiell Kolthoff's Sphecidenund Tiphiiden-Ausbeneute aus China. - Arkiv für Zoologie 30A, 15: 1-16.

Kazenas, V. L. 1978: The digger wasps of Kazakhstan and Middle Asia (Sphecidae). The de Tenuinant Academy of Science of Kazakh SSR, Institute of Zoology, Alma-Ata. 172 pp.

Porter C. C., Stange L. A. and Wang, H. Y. 1999: Checklist of the Sphecidae of Taiwan with a key to genera (Hymenoptera: Sphecidae). - Journal of the National Taiwan Museum 52: 1-26.

Pu, T. 1986: New records of Sphecidae from China. — Entomotaxonomia 8: 8 .

Pulawski, W. J. 2007: Catalog of Sphecidae. [www document]. URL http://www.calacademy.org/RESEARCH/entomology/Entomology_Resources/Hymenoptera/sphecidae/Genera_and_species_PDF/Liris. pdf. 61 pp. (Site visited on 23 April, 2007).

Richards, O. W. 1928: The Species of Notogonia (Hymenoptera, Larridae) ocuring in Mediterranean Basin. Proceedings of the General Meetings for Scientific Business of the Zoological Society of London, pp. 357-363.

Smith, F. 1856: Catalogue of hymenopterous insects in the collection of the British Museum. Part IV. Sphegidae, Larridae and Crabronidae. - Taylor and Francis, London, pp. 207-497.
Tsuneki, K. 1966: Contribution to the knowledge of the Larrinae fauna of Formosa and Kyukyus. (Hymenoptera, Sphecidae). - Etizenia 17: 1-15.

Tsuneki, K. 1967: Studies on the Formosan Sphecidae (I). The subfamily Larrinae. - Etizenia 20: 1-60.

Tsuneki, K. 1971: Studies on the Formosan Sphecidae. (XI). A supplement to the subfamily Larrinae (Hymenoptera). - Etizenia 55: 1-21, 88 Figs.

Tsuneki, K. 1972: Studies on the Formosan Sphecidae (XIV). Notes on some specimens newly examined, with a description of a related Japanese subspecies (Hymenoptera). — Etizenia 60: 1-13, 25 Figs.

Tsuneki, K. 1982: Sphecidae collected by the Noona Dan Expedition to the Bismarck and Solomon archipelagoes (Hymenoptera). - Special Publications of the Japan Hymenopterists Association 19: 1-58.

Williams, F. X. 1928: Studies in tropical wasps - their hosts and associates (with descriptions of new species). Bulletin of the Hawaiian Sugar Planters Association, Entomological Series 19: 61-111.

Wu, Y. R. and Zhou, Q. 1996: Larrinae. — In: Wu, Y. R. and Zhou, Q. 1996 (eds.), Economic insect fauna of China. Fasc.52. Hymenoptera: Sphecidae. Science Press, Beijing, pp. 75-82. 